\title{
FOREST STRUCTURE AND FIRE HISTORY AT LAKE ARCADIA, OKLAHOMA COUNTY, OKLAHOMA (1820-2014)
}

\author{
Chad B. King \\ Department of Biology \\ University of Central Oklahoma \\ Edmond, OK 73034 \\ cking24@uco.edu
}

Keywords: fire history, Cross Timbers, dendroecology

\begin{abstract}
Evidence indicates that the structure of Oklahoma Cross Timbers forests are in transition due to changing climate, land-use patterns, and fire suppression efforts. However, only a handful of studies have addressed the history of fire across the Oklahoma Cross Timbers landscape. This research adds to the body of literature by studying the contemporary forest structure and fire history at Lake Arcadia in Oklahoma County, Oklahoma. Results demonstrate that post oak (Quercus stellata Wangenh.) and blackjack oak (Q. marilandica Münchh.), two common species in Oklahoma Cross Timbers, dominate the forest. However, several mesophytic tree species are found in the overstory as well as the sapling layer of the forest. A total of 25 fire events (mean fire interval $=4.14$ years) were documented during the $20^{\text {th }}$ century using fire-scar analysis of Q. stellata trees and remnant wood (stumps, snags, recently dead trees). High fire frequencies in the early to mid-20 ${ }^{\text {th }}$ century corresponded to the recruitment of $Q$. stellata and $Q$. marilandica. Wet conditions (PDSI $>0$ ) during the late $20^{\text {th }}$ century and no fires after 1985 corresponded to the recruitment of non-oak, mesophytic species at the study site. The results of this study suggest that changes in fire frequency and moisture availability are contributing to changes in tree density and species composition at the study site.

\section{INTRODUCTION}

Fire has long been recognized as an important driver of forest dynamics (Pyne 1982). In eastern North America, fire was a likely contributor to the development and sustainment of oak (Quercus spp.) forests (Abrams 1992). Anthropogenic fire likely played a role in promoting upland oak forests, as well as changes in these forests (Guyette et al. 2002). Several upland Quercus species benefit from and are adapted to frequent surface fires for their regeneration and recruitment in forests (Abrams 1992). However, fire suppression during the $20^{\text {th }}$ century has led to increasing densities of fire-sensitive, mesophytic tree species and a decline in Quercus density (Nowacki and Abrams 2008).

Understanding the frequency of historic fires has an important role in explaining changes to contemporary forests. The result is a rich history of studies of fire history across the eastern United States (Shumway et al. 2001; Guyette et al. 2006; McEwan et al. 2007; King and Muzika 2014; Muzika et al. 2015; among others). One of the common patterns found in these studies is that surface fires were often frequent events prior to Euro-American settlement of the area and that fire remained frequent during early Euro-American settlement prior to fire suppression efforts in the early and mid- $20^{\text {th }}$ century. Several interacting factors likely contributed to changing fire frequencies in eastern North American forests, including human density, topography, drought, and
\end{abstract}


climate change (Guyette et al. 2002;

McEwan et al. 2011).

Recently, research on forest structure and dynamics in Oklahoma Cross Timbers forests and savannas has highlighted the increase in fire-sensitive tree density and decrease in Quercus density since the 1950s attributed to drought and fire suppression efforts (DeSantis et al. 2011). Fire history studies in the Oklahoma Cross Timbers have demonstrated frequent fires prior to Euro-American settlement and a continued presence of fire on the landscape into the mid-20 ${ }^{\text {th }}$ century (Shirakura 2003; Clark et al. 2007; Stambaugh et al. 2009; DeSantis et al. 2010a; Allen and Palmer 2011).

This research adds to the growing body of literature of forest dynamics and fire history in the Oklahoma Cross Timbers. Preliminary investigation of the Arcadia Conservation Education Area in northeast Oklahoma County revealed the presence of fire scarred trees and remnant wood indicative of historic fires at the site. This research had two objectives: 1 ) describe the contemporary forest structure by analyzing species composition, density, basal area, and age structure in the overstory and sapling layers of the forest and 2) relate the forest structure to the frequency of historic fires using dendrochronology.

\section{METHODS}

\section{Study Site}

Lake Arcadia is an approximately 736 ha recreational and water supply lake located in northeastern Oklahoma County. The Army Corps of Engineers constructed the lake beginning in 1980 with the lake pool filling by 1987 . The study site was located on the south side of the lake at the Arcadia Conservation Education Area (ACEA) (35'37'29'N, $\left.97^{\circ} 23^{\prime} 16^{\prime \prime} \mathrm{W}\right)$. The ACEA is an approximately 226 ha area administered by the Oklahoma Department of Wildlife Conservation since 1996; prescribed fire is not utilized at the site (D. Griffith, Area
Manager, pers. comm.). Mean annual temperature is $15.63^{\circ} \mathrm{C}$, and mean annual precipitation is $91.4 \mathrm{~cm}$. Annual precipitation is bimodal with the greatest amounts of precipitation during May-June and September-October (Oklahoma Climatological Survey, www.mesonet.org). Soils in this area are classified as Stephenville-Darnell-Niotaze, characterized by shallow sandy to loamy soils (Dominick 2003; Carter and Gregory 2008). Elevations at the study site range from $308.5 \mathrm{~m}$ at the lake edge to $323.4 \mathrm{~m}$ at the southern boundary of the ACEA.

Preliminary investigation revealed fire scarred trees and remnant wood within a 43 ha area of the ACEA. The focus of this research was within the 43 ha area to study the fire history and forest composition and structure.

\section{Forest Composition, Age Structure, and Radial Growth}

Stand structure data were collected on twenty 0.04 ha fixed-area plots located randomly within the 43 ha study area. Within each plot, the diameter at breast height (DBH) of all overstory trees (DBH $>10 \mathrm{~cm}$ ) was measured, and trees were identified to species. For each species in the overstory, estimates of relative density (trees/ha), relative dominance (basal area/ha), and relative importance were calculated to describe the contemporary composition of the forest overstory. Increment cores were collected at $30 \mathrm{~cm}$ above the ground from two to four of the largest overstory trees per plot for estimates of age structure and radial growth at the study site. Tree selection was based on the development of the longest tree-ring chronology for the site which can limit age structure interpretation. A total of 71 increment cores were collected from ACEA.

Two 0.01 ha fixed-area subplots were established in each 0.04 ha overstory plot to analyze the species composition and density of saplings (DBH $<10 \mathrm{~cm},>1.37 \mathrm{~m}$ height). 
Saplings were identified to species and counted within each subplot. Cross-sections of one to two saplings were collected from paired subplots to study the age structure and radial growth of saplings.

Increment cores were returned to the University of Central Oklahoma where they were mounted and sanded with progressively finer sandpaper (80-grit to 1200 -grit) in order to see individual tree-ring boundaries and cellular structure (Stokes and Smiley 1996). Cross-dating procedures were used to confidently assign calendar years to each tree-ring on an increment core. Individual ring-width measurements, to the nearest $0.01 \mathrm{~mm}$, were collected on each sample using a Velmex TA Unislide System (Velmex, Inc., Bloomfield, NY), binocular microscope, and J2X measurement software (Voortech Consulting, Holderness, NH). Tree-ring series measurements were compared graphically, using the list method (Yamaguchi 1991), and statistically using the program COFECHA (Holmes 1983; Grissino-Mayer 2001a). Following crossdating and assignment of calendar years to each tree-ring, pith dates were recorded for age estimation at coring height and tree cohort establishment at the study site. In the event that the pith was missed in an increment core, the methods of Duncan (1989) were used to estimate the number of tree-rings missed to the pith of the tree.

\section{Fire History}

Cross-sections were collected selectively from Q. stellata remnant wood to study the fire history of the site. Quercus stellata has been used successfully for fire history studies in Oklahoma Cross Timbers (Clark et al. 2007; Stambaugh et al. 2009; DeSantis et al. 2010b; Allen and Palmer 2011). The analysis approach of Guyette and Stambaugh (2004) was used to identify fire scars in Q. stellata. In their study, fire scars were identified based on bark fissure patterns, common in oak species (Smith and
Sutherland 2001), and scarring that occurs across multiple samples during the same year.

A total of 21 samples exhibited scarring associated with surface fires, including 13 recently dead Q. stellata, two saplings that demonstrated fire scars, and six snags. Three samples could not be successfully cross-dated. All samples were sanded with progressively finer sandpaper (80-grit to 1200-grit). Ring-widths for each remnant sample were measured using the Velmex TA Unislide System (Velmex, Inc., Bloomfield, $\mathrm{NY}$ ), binocular microscope, and J2X measurement software (Voortech Consulting, Holderness, NH). Based on cross-dating, calendar years for each treering on fire-scarred samples were assigned using correlation analysis with a master treering chronology created from 39 cross-dated Q. stellata tree-ring series from the study site.

Calendar years were assigned to each identified fire scar on a sample. A fire chronology was created based on all fire scars for analysis of fire frequency (mean fire interval) and fire severity (fire years in which $>25 \%$ samples were scarred) using the program FHX2 (Grissino-Mayer 2001b). Superposed epoch analysis (Grissino-Mayer 2001b) was used to test the association of fire year and drought. Instrumental Palmer Drought Severity Index (Palmer 1965) data for the time period 1895 to 2013 from Oklahoma Climate Region 5 were used to associate fire year and drought. An average was calculated for Reconstructed Palmer Drought Severity Index (Cook et al. 2004) for gridpoint 178 and 179 for purposes of comparing drought and growth of trees prior to 1895. Reconstructed Palmer Drought Severity Indices are reconstruction models based on the association of instrumental Palmer Drought Severity Indices and regional tree-ring chronologies (Cook et al. 1999). 


\section{RESULTS}

A total of nine species were identified in the overstory at Lake Arcadia. Quercus stellata was the most dominant species, but $Q$. marilandica had the highest density. Overall, these two species accounted for $88 \%$ of the basal area and $68 \%$ of the overstory tree density at the study site. Two Celtis species (C. laevigata Willd.; C. occidentalis L.) combined had the third highest relative tree density $(15.1 \%)$ and relative dominance $(5.51 \%)$ (Table 1$)$.

Table 1 Overstory (DBH $>10 \mathrm{~cm})$ statistics and sapling $(\mathrm{DBH}<10 \mathrm{~cm},>1.37 \mathrm{~m}$ height) density at Lake Arcadia, Oklahoma County, Oklahoma. Relative importance value $=($ relative density + relative dominance) $/ 2$.

\begin{tabular}{|c|c|c|c|c|c|c|}
\hline Species & Trees/ha & $\begin{array}{l}\text { Relative } \\
\text { Density }\end{array}$ & $\begin{array}{c}\text { Basal Area } \\
\left(\mathrm{m}^{2} / \mathrm{ha}\right)\end{array}$ & $\begin{array}{c}\text { Relative } \\
\text { Dominance }\end{array}$ & $\begin{array}{c}\text { Relative } \\
\text { Importance } \\
\text { Value }\end{array}$ & $\begin{array}{c}\text { Sapling } \\
\text { Density } \\
\text { (stems/ha) }\end{array}$ \\
\hline Quercus stellata & 95 & 29.2 & 14.5 & 70.1 & 49.7 & 576 \\
\hline Quercus marilandica & 126 & 38.8 & 3.66 & 17.7 & 28.3 & 480 \\
\hline Celtis laevigata & 28 & 8.62 & 0.71 & 3.47 & 6.04 & 192 \\
\hline Juniperus virginiana & 25 & 7.69 & 0.78 & 3.77 & 5.73 & 384 \\
\hline Celtis occidentalis & 21 & 6.46 & 0.42 & 2.05 & 4.25 & 1056 \\
\hline Ulmus rubra & 15 & 4.62 & 0.50 & 2.41 & 3.51 & 192 \\
\hline $\begin{array}{l}\text { Sideroxylon } \\
\text { lanuginosum }\end{array}$ & 7 & 2.15 & 0.06 & 0.27 & 1.21 & --- \\
\hline Ulmus americana & 4 & 1.23 & 0.03 & 0.12 & 0.68 & 96 \\
\hline Sapindus drummondii & 4 & 1.23 & 0.01 & 0.05 & 0.64 & --- \\
\hline Cornus drummondii & --- & --- & --- & --- & --- & 384 \\
\hline Cercis canadensis & --- & --- & --- & --- & --- & 192 \\
\hline Quercus mueblenbergï & --- & --- & --- & --- & --- & 96 \\
\hline Celtis reticulata & --- & --- & --- & --- & --- & 96 \\
\hline Total & 325 & 100 & 20.6 & 100 & 100 & 3744 \\
\hline
\end{tabular}

A total of 11 species was found in the sapling layer (see Table 1). The sapling layer was rather dense (3,744 stems/ha). Celtis occidentalis had the highest sapling density (1,056 stems/ha), and the three Celtis species accounted for $35 \%$ of the sapling density at Lake Arcadia. Approximately $78 \%$ of the overstory tree species was also found in the sapling layer; the exceptions were Sapindus drummondii Hook \& Arn. and Sideroxylon 
lanuginosum Michx. Two species, that have the potential of growing up to the existing overstory, were identified in the sapling layer but were not found in the overstory (C. reticulata Torr.; Q. mueblenbergii Engelm.). A total of 137 samples from nine species was collected for analysis of forest age structure, radial growth, and fire history at Lake Arcadia. Quercus stellata and $Q$. marilandica accounted for $71 \%(\mathrm{n}=97)$ of the samples. Increment cores were collected from Q. stellata $(\mathrm{n}=39), Q$. marilandica $(\mathrm{n}=16), S$. drummondii $(\mathrm{n}=1)$, Ulmus americana (L.) ( $\mathrm{n}=1)$, U. rubra (Muhl.) $(\mathrm{n}=3)$, S. lanuginosum $(\mathrm{n}=2)$, C. laevigata $(\mathrm{n}=3)$, and C. occidentalis $(\mathrm{n}=6)$. Sapling cross-sections were collected from Q. stellata $(\mathrm{n}=5)$, Q. marilandica $(\mathrm{n}=16)$, S. lanuginosum $(\mathrm{n}=2)$, C. laevigata $(\mathrm{n}=8)$, C. occidentalis ( $\mathrm{n}=10)$, and Juniperus virginiana (L.) $(n=4)$ for estimates of sapling age and radial growth. A total of 21 Q. stellata samples exhibited scarring associated with surface fires. Two Q. stellata saplings exhibited fire scars.
The largest diameter tree in our study plots was a Q. stellata that measured $67.5 \mathrm{~cm}$ $\mathrm{DBH}$. The oldest tree was a Q. stellata that was 193 years old (1821-2014). However, only $23.3 \%$ of $Q$. stellata trees dated prior to the $20^{\text {th }}$ century (Fig. 1). The oldest $Q$. marilandica in our study plots was 108 years old (1906-2014). Q. stellata demonstrated continuous recruitment beginning in the 1880s, with the 1910s having the recruitment of a large cohort (see Fig. 1). Q. marilandica also demonstrated continuous recruitment during the early and mid- $20^{\text {th }}$ century. The oldest non-Quercus individual in the overstory was a $C$. occidentalis that was 62 years old (1952-2014). The age structure of the non-Quercus species in the overstory (S. drummondii, U. americana, U. rubra, S. lanuginosum, C. laevigata, C. occidentalis) indicated continuous recruitment beginning in the 1950s and peaking during the 1980s (see Fig. 1).

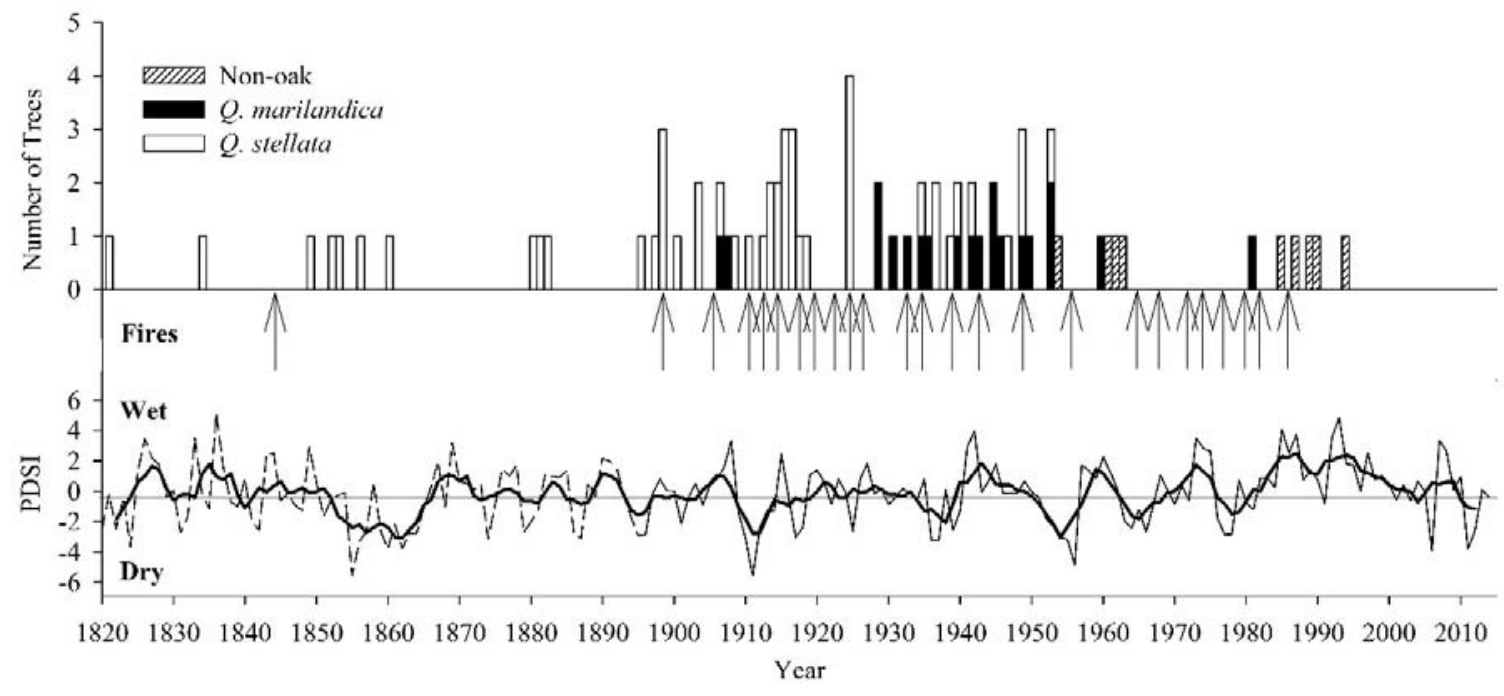

Figure 1 Age structure of Q. stellata, Q. marilandica, and non-oak species. Non-oak species include S. lanuginosum, C. laevigata, C. occidentalis, S. drummondii, U. americana, U. rubra. Arrows indicate the year of a fire. Bottom graph represents reconstructed (dashed line) and instrumental (full line) Palmer Drought Severity Index (PDSI) for central Oklahoma. 
The oldest sapling in the understory of the study plots was a $Q$. marilandica that was 62 years old (1952-2014). Approximately $49 \%(\mathrm{n}=19)$ of non-oak saplings recruited during the 1980s (Fig. 2). Establishment of non-oak species appeared to correspond to periods of above-average PDSI following the 1960s (see Figs. 1, 2).

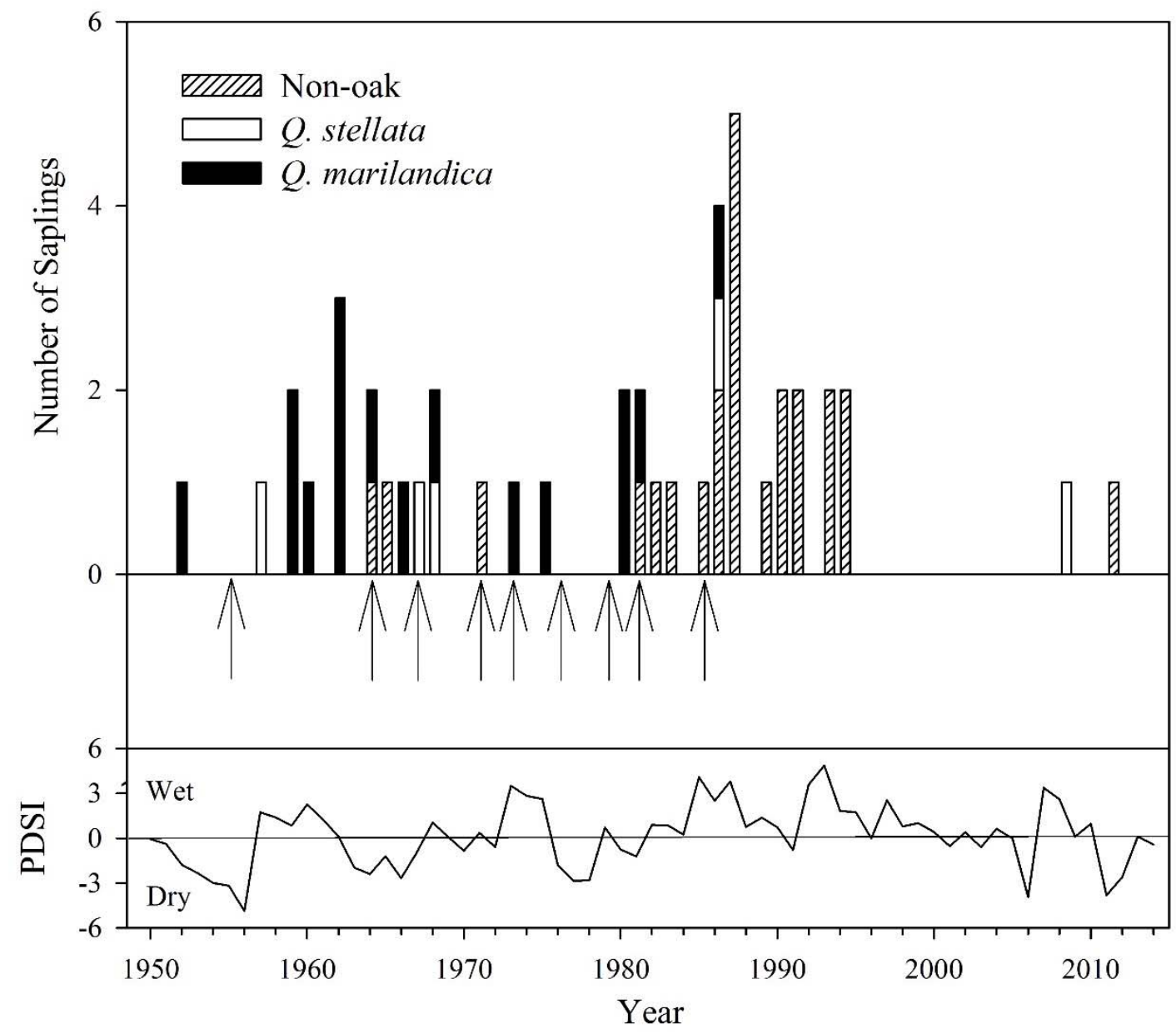

Figure 2 Age structure of Q. stellata, Q. marilandica, and non-oak saplings at Lake Arcadia. Non-oak species includes S. lanuginosum, C. laevigata, C. occidentalis, and J. virginiana. Arrows represent years of fire. Bottom graph is the instrumental PDSI for central Oklahoma (1952-2014).

Fifty-one fire scars were identified and dated, that occurred from 25 different fire events (Fig. 3). The earliest fire occurred in 1844 with a range of fire years from 1844 to 1985. However, the 1844 fire scar was not used in any of the fire analyses due to a low sample depth during that time period it and being represented on only one sample. Approximately 29.7\% of years 1898 to 1985 had a fire. The most severe fire years (based on percentage of trees scarred) included 1898 (33.3\%), 1912 (55.6\%), 1922 (41.7\%), and $1955(41.7 \%)$. The mean fire interval (MFI) for all fires from 1898 to 1985 was 4.14 years ( $\mathrm{SD} \pm 2.22$, range $2-9$ years). Superposed epoch analysis was conducted to test the association between drought and any fire year. Results indicated no significant association between any fire year (1898 to 1985) and drought (Fig. 4). Severe fires 
during 1912 and 1955 were associated with extreme drought conditions (PDSI $\leq-2.99$ ). For the period 1898 to 1985,13 fires occurred during dry conditions (PDSI $<0$ ), and 11 fires occurred during wet conditions (PDSI > 0).

\section{DISCUSSION}

Changes in historic fire regimes and land-use patterns often lead to changes in forest structure and composition. In the Cross Timbers region of Oklahoma, changes in forest structure and composition are apparent in terms of increasing tree density, particularly increases in fire sensitive tree species (DeSantis et al. 2010a, 2011). The result of changing historic forest dynamics is the "mesophication" (Nowacki and Abrams 2008) of Cross Timbers forests. This study demonstrates the continued dominance of $Q$. stellata and Q. marilandica in the overstory of this Cross Timbers forest.
However, this study also highlights the effect of a changing fire regime on forest structure at the study site.

Total basal area for this study is similar to other studies across multiple sites in the Oklahoma Cross Timbers (DeSantis et al. 2010a, 2011) and Arkansas Cross Timbers (Bragg et al. 2012). DeSantis et al. (2010a) demonstrate increases in non-oak basal area and tree density across multiple sites in Oklahoma between the 1950s and 2000s. This study shows that Celtis species collectively make up the third most important group at the study site (see Table 1). The two Celtis species, Juniperus virginiana and Ulmus species, in this study along with the other non-oak species are sensitive to fire as seedlings and saplings (Coladonato 1992, 1993; Sullivan 1993; Anderson 2003; Gucker 2011). Generally, only the most severe fires will kill overstory trees of these species.

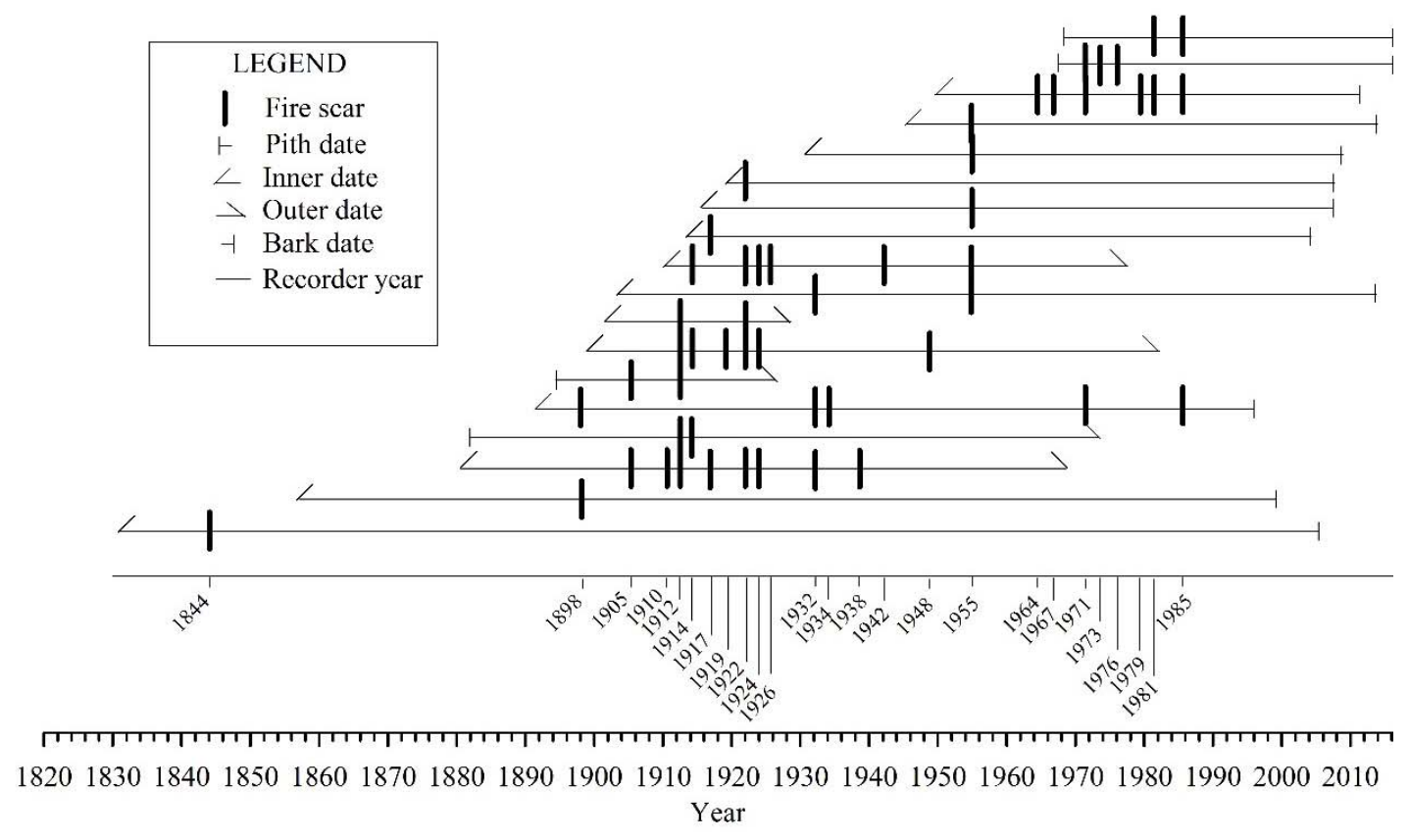

Figure 3 Fire history graph for Lake Arcadia in northeastern Oklahoma County, Oklahoma. Horizontal lines represent the length of the tree-ring record for each sample $(\mathrm{n}=18)$. Vertical dashes represent the year of a fire scar in each tree-ring record. The composite fire chronology is represented by the fire years. 


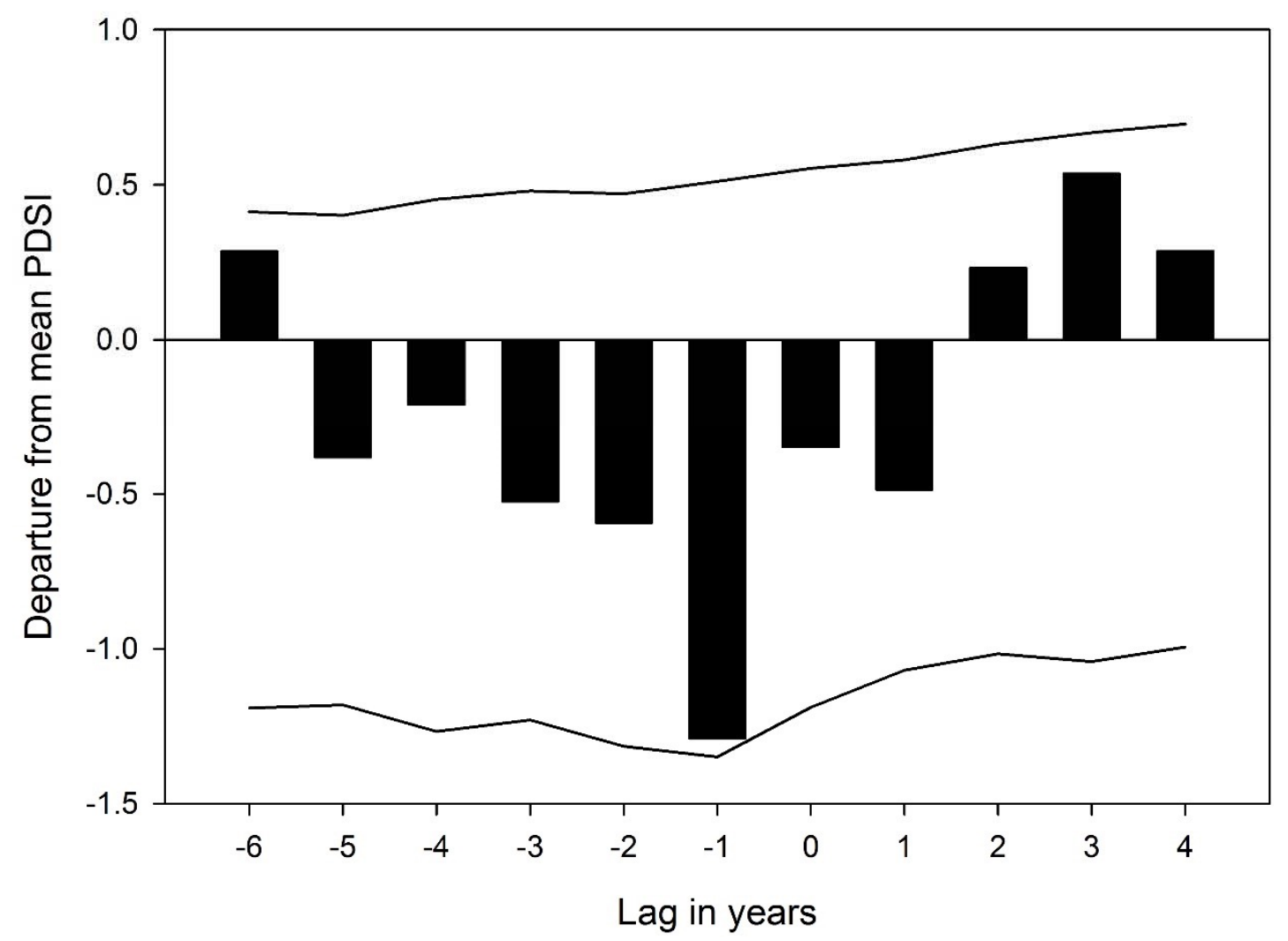

Figure 4 Superposed epoch analysis for all fires from 1898 to 1985 compared to PDSI (drought). This program analyzes the relationship between any fire year and drought (Grissino-Mayer 2001b). Year " 0 " is the year of any fire year; Year " 1 " indicates the departure from the mean PDSI one year prior to any fire year. Horizontal lines represent 95\% confidence interval based on 1000 Monte Carlo simulations.

This study highlights the recruitment of a large number of non-oak trees during the 1980s (see Figs. 1, 2). There are two factors which likely contributed to this recruitment. The last fire that was documented at Lake Arcadia occurred in 1985 (see Fig. 3).

Additionally, following the drought during the late 1970s and early 1980s in the central Oklahoma region was an 18 year period (1982-2000) of above-average PDSI (see Figs. 1, 2). This 18 year period along with no fires after 1985 likely contributed to recruitment of these non-oak species. The data also show recruitment of non-oak trees following the 1950s drought (see Figs. 1, 2).
DeSantis et al. (2011) found increases in species recruitment following drought during the 1950s and decreases in Quercus recruitment associated with fire suppression. Clark et al. (2007) indicated increased recruitment of J. virginiana during fire free periods and increased recruitment of Quercus species following frequent fires. The results of this study also suggest that fire-free periods (between 1955 and 1964; post-1985) (see Fig. 3) contributed to non-oak recruitment at Lake Arcadia. The 1964 and 1967 fires are represented on only one sample, which may suggest that these fires were of low severity and had little effect on non-oak recruitment during this time 
period. Recruitment of Q. stellata during the early $20^{\text {th }}$ century occurred during high fire frequency (1905-1926, MFI = 2.62 years). Following 1926, the number of fires declined to seven in a 38 year period (19261964). The current $Q$. marilandica overstory recruited during the mid- $20^{\text {th }}$ century period, which coincided with surface fires.

The fire frequency at Lake Arcadia (MFI $=4.14$ years) is within the range of other studies in the Cross Timbers and other mixed-species forests of Oklahoma. DeSantis et al. (2010b) in Okmulgee County reported an MFI equal to 2.7 years for the time period 1750 to 2005 . When considering a similar time period to this study, they report an MFI of 2 years. Clark et al. (2007) indicated a range of fire frequency between 2.5 and 6 years (17702002) based on the aspect of the forest stand at sites in Osage County. Allen and Palmer (2011) report an MFI for all fires of 2.3 years (1729-2005) at a different site in Osage County. Stambaugh et al. (2009) at the Wichita Mountains National Wildlife Refuge found an MFI of 4.7 years for all fires between 1722 and 2001. At the Nickel Family Nature and Wildlife Preserve in northeastern Oklahoma, Stambaugh et al. (2013) found a fire frequency of 2.6 years in a mixed oak-pine (Quercus-Pinus) forest. Masters et al. (1995) in a study of fire history in McCurtain County reported a mean fire interval of 3.8 years.

Comparing the association between drought and fire year revealed no significant association at Lake Arcadia (see Fig. 4). This result is similar to other studies in the Oklahoma Cross Timbers (Allen and Palmer 2011; DeSantis et al. 2010b; Stambaugh et al. 2009) and contrary to that reported by Clark et al. (2007). Three of four severe fire years $(1898,1912,1955)$ coincided with below average PDSI (drought) conditions. The exception was the 1922 severe fire year which coincided with above average PDSI.
In all previous studies of fire history in the Oklahoma Cross Timbers, fires were found to be frequent events prior to EuroAmerican settlement $(<1890)$ and after EuroAmerican settlement $(>1890)$. There is a noticeable lack of fires between 1844 and 1898 (see Fig. 3). There are several possible explanations for the absence of fire scars. Not every fire which occurs at a site will result in the formation of a fire scar. Most remnant samples had only heartwood present that often resulted in too few tree-rings to accurately cross-date. Decomposition of the heartwood was also a common feature of the trees at Lake Arcadia that possibly resulted in the loss of fire scars that were present during the mid and late $19^{\text {th }}$ century. However, even with the limited temporal scope of the fire history, this study demonstrates frequent fires at the Lake Arcadia area during the $20^{\text {th }}$ century.

\section{CONCLUSIONS}

Fire was likely an important factor that sustained the dominance of Quercus species in upland forests (Abrams 1992). While this study has some limitations, it does highlight Quercus recruitment coincided with frequent fires during the $20^{\text {th }}$ century. Changes in fire frequency after 1985 and fire-free periods promoted non-oak recruitment in the understory, similar to other studies in the Oklahoma Cross Timbers (Clark et al. 2007) and across other upland Quercus forests in the eastern United States (Abrams 1992). Studies of fire history are important for understanding forest development, the historical role of humans on the landscape, and the development of management guidelines for sites which utilize prescribed fire. This study adds to the growing knowledge of historic fire frequency in the Oklahoma Cross Timbers. Fires were frequent events that shaped the historic Cross Timbers, and often the high frequencies continued into the mid and late $20^{\text {th }}$ century. Comparatively, the number of 
studies that have specifically addressed fire history in the Oklahoma Cross Timbers is limited. Other sites should be selected and studied to further expand the knowledge of historic fire on the Cross Timbers landscape.

\section{ACKNOWLEDGEMENTS}

I would like to thank Justin Cheek and Shey Ramsey at the University of Central Oklahoma for their assistance in the field and laboratory. I would like to graciously thank Daniel Griffith at the Arcadia Conservation Education Area for permission to collect samples at the study site. Thanks to two anonymous reviewers for constructive comments and suggestions on an earlier version of this manuscript. This research was supported by the Office of Research and Grants at the University of Central Oklahoma.

\section{LITERATURE CITED}

Abrams, M.D. 1992. Fire and the development of oak forests. Bioscience 42:346-353.

Allen, M.S. and M.W. Palmer. 2011. Fire history of a prairie/forest boundary: More than 250 years of frequent fire in a North American tallgrass prairie. Journal of Vegetation Science 22:436-444.

Anderson, M.D. 2003. Juniperus virginiana. In: Fire Effects Information System. U.S. Department of Agriculture, Forest Service, Rocky Mountain Research Station, Fire Sciences Laboratory (Producer). http://www.fs.fed.us/database/feis/ (16 July 2015).

Bragg, D.C., D.W. Stahle, and K.C. Cerny. 2012. Structural attributes of two oldgrowth Cross Timbers stands in western Arkansas. American Midland Naturalist 167:40-55.
Carter, B.J. and M.S. Gregory. 2008. Soil Map of Oklahoma. Norman (OK): Oklahoma Geological Survey.

Clark, S.L., S.W. Hallgren, D.M. Engle, and D.W. Stahle. 2007. The historic fire regime on the edge of the prairie: A case study from the Cross Timbers of Oklahoma. pp. 40-49. In: Masters, R.E., K.E.M. Galley (eds.). Proceedings of the $23^{\text {rd }}$ Tall Timbers Fire Ecology Conference: Fire in Grassland and Shrubland Ecosystems. Tallahassee (FL): Tall Timbers Research Station.

Coladonato, M. 1992. Ulmus americana. In: Fire Effects Information System. U.S. Department of Agriculture, Forest Service, Rocky Mountain Research Station, Fire Sciences Laboratory (Producer). http://www.fs.fed.us/database/feis/ (16 July 2015).

Coladonato, M. 1993. Ulmus rubra. In: Fire Effects Information System. U.S. Department of Agriculture, Forest Service, Rocky Mountain Research Station, FireSciences Laboratory (Producer). http://www.fs.fed.us/database/feis/ (16 July 2015).

Cook, E.R., D.M. Meko, D.W. Stahle, and M.K. Cleaveland. 1999. Drought reconstructions for the continental United States. Journal of Climate 12:11451162.

Cook, E.R., D.M. Meko, D.W. Stahle, and M.K. Cleaveland. 2004. North American Summer PDSI Reconstructions. IGBP PAGES/World Data Center for Paleoclimatology Data Contribution Series. Boulder (CO): NOAA NGDC Paleoclimatology Program.

DeSantis, R.D., S.W. Hallgren, T.B. Lynch, J.A. Burton, and M.W. Palmer. 2010a. Long-term directional changes in upland Quercus forests throughout Oklahoma, USA. Journal of Vegetation Science 21:606615. 
Desantis, R.D., S.W. Hallgren, and D.W. Stahle. 2010b. Historic fire regime of an upland oak forest in south-central North America. Fire Ecology 6:45-61.

DeSantis, R.D., S.W. Hallgren, and D.W. Stahle. 2011. Drought and fire suppression lead to rapid forest composition change in a forest-prairie ecotone. Forest Ecology and Management 261:1833-1840.

Dominick, M.D. 2003. Soil Survey of Oklahoma County. United States Department of Agriculture, Natural Resources Conservation Service.

Duncan, R.P. 1989. An evaluation of error in tree age estimates based on increment cores in Kahikatea (Dacrycarpus dacrydioides). New Zealand Natural Sciences 16:31-37.

Grissino-Mayer, H.D. 2001a. Evaluating crossdating accuracy: A manual and tutorial for the computer program COFECHA. Tree-Ring Research 57:205221.

Grissino-Mayer, H.D. 2001b. FHX2 software for analyzing temporal and spatial patterns in fire regimes from tree rings. Tree-Ring Research 57:115-124.

Gucker, C.L. 2011. Celtis occidentalis. In: Fire Effects Information System. U.S. Department of Agriculture, Forest Service, Rocky Mountain Research Station, Fire Sciences Laboratory (Producer). http://www.fs.fed.us/database/feis/ (16 July 2015).

Guyette, R.P, R.M. Muzika, and D.C. Dey. 2002. Dynamics of an anthropogenic fire regime. Ecosystems 5:472-486.

Guyette, R.P. and M.C. Stambaugh. 2004. Post oak fire scars as a function of diameter, growth, and tree age. Forest Ecology and Management 198:183-192.

Guyette, R.P., D.C. Dey, M.C. Stambaugh, and R.M. Muzika. 2006. Fire scars reveal variability and dynamics of eastern fire regimes. pp. 20-39. In: Dickinson, M.B. (ed.). Proceedings of the conference:
Fire in eastern oak forests: delivering science to land managers. Vol. GTRNRS-P-1. Columbus (OH): Ohio State University. U.S. Department of Agriculture, U.S. Forest Service, Northern Research Station.

Holmes, R.L. 1983. Computer-assisted quality control in tree-ring dating and measurement. Tree-Ring Bulletin 43:6978.

King, C.B. and R.M. Muzika. 2014. Historic fire and canopy disturbance dynamics in an oak-pine (Quercus-Pinus) forest of the Missouri Ozarks. Castanea 79:78-87.

Masters, R.E., J.E. Skeen, and J. Whitehead. 1995. Preliminary fire history of

McCurtain County Wilderness Area and implications for red-cockaded woodpecker management. pp. 290-302. In: Kulhavy, D.L., R.G. Hooper, and R. Cost (eds.). Red-cockaded Woodpecker Symposium III: Recovery, Ecology and Management, 24-28 January 1993, North Charleston, South Carolina. Nacogdoches (TX): Stephen F. Austin State University, College of Forestry, Center for Applied Studies in Forestry. McEwan, R.W., T.F. Hutchinson, R.P. Long, D.R. Ford, and B.C. McCarthy. 2007. Temporal and spatial patterns of fire occurrence during the establishment of mixed-oak forests in eastern North America. Journal of $V$ egetation Science 18:655-664.

McEwan, R.W., J.M. Dyer, and N. Pederson. 2011. Multiple interacting ecosystem drivers: Toward an encompassing hypothesis of oak forest dynamics across eastern North America. Ecograpby 34:244-256.

Muzika, R.M., R.P. Guyette, M.C. Stambaugh, and J.M. Marschall. 2015. Fire, drought, and humans in a heterogeneous Lake Superior landscape. Journal of Sustainable Forestry 34:49-70.

Nowacki, G.J. and M.D. Abrams. 2008. The demise of fire and "mesophication" of 
forests in the eastern United States. Bioscience 58:123-138.

Palmer, W.C. 1965. Meteorological drought. Research Paper 45. Washington (DC): U.S. Department of Commerce, Weather Bureau.

Pyne, S.J. 1982. Fire in America: A Cultural History of Wildland and Rural Fire. Princeton (NJ): Princeton University Press.

Shirakura, F. 2003. Tornado Damage and Fire History in the Cross Timbers of the Tallgrass Prairie Preserve, Oklaboma [Master's thesis]. Stillwater $(\mathrm{OK})$ : Oklahoma State University.

Shumway, D.L., M.D. Abrams, and C.M. Ruffner. 2001. A 400-year history of fire and oak recruitment in an old-growth forest in western Maryland, U.S.A. Canadian Journal of Forest Research 31:1437-1443.

Stambaugh, M.C., R.P. Guyete, R. Godfrey, E.R. McMurry, and J.M. Marschall.
2009. Fire, drought, and human history near the western terminus of the Cross Timbers, Wichita Mountains, Oklahoma, USA. Fire Ecology 5:51-64. Smith, K.T. and E.K. Sutherland. 2001. Terminology and biology of fire scars in selected central hardwoods. Tree-Ring Research 57:141-147.

Stokes, M.A. and T.L. Smiley. 1996. An Introduction to Tree-Ring Dating. Chicago (IL): University of Chicago Press. Sullivan, J. 1993. Celtis laevigata. In: Fire Effects Information System. U.S. Department of Agriculture, Forest Service, Rocky Mountain Research Station, Fire Sciences Laboratory (Producer). http://www.fs.fed.us/database/feis/ (16 July 2015).

Yamaguchi, D.K. 1991. A simple method for cross-dating increment cores from living trees. Canadian Journal of Forest Research 21:414-416. 